\title{
Aspergillosis in domestic and wild birds from Argentina
}

\section{Aspergilose em aves domésticas e silvestres da Argentina}

\author{
Romina Della Vedova1 (1); Alejandra Hevia²; Walter Vivot²; Julián Fernández²; Susana Beatriz Córdoba ${ }^{1,2}$ (D); \\ Francisco José Reynaldi ${ }^{1,3}$ (D)
}

\footnotetext{
${ }^{1}$ Universidad Nacional de La Plata, Facultad de Ciencias Veterinarias, Departamento de Microbiología, La Plata - Buenos Aires, Argentina

${ }^{2}$ Administración Nacional de Laboratorios e Institutos de Salud “Dr. Carlos G. Malbrán”, Instituto Nacional de Enfermedades Infecciosas Agudas “Dr. Carlos G. Malbrán”, Departamento Micología, CABA - Buenos Aires, Argentina

${ }^{3}$ Centro Científico Tecnológico, Consejo Nacional de Investigaciones Científicas y Técnicas, La Plata - Buenos Aires, Argentina
}

\begin{abstract}
Aspergillus species are widely distributed throughout the world and can develop parasitic and saprophytic ways of life, allowing Aspergillus to infect living hosts, including plants, insects, birds and mammals. The most common form of aspergillosis in poultry and other birds is respiratory infection. Clinical manifestations depend on the infective dose, pre-existing diseases, and the immune response of the host. The aim of the present research was to study aspergillosis in domestic and wild birds from Argentina. We carried out morphological and molecular identification, and determination of antifungal susceptibility against seven antifungal drugs. Six birds from different cities of Buenos Aires Province of Argentina were studied. Three of the samples belonged to broiler chicks, while the other three belonged to an eagle, a pheasant, and a kelp gull. Two isolates were identified as Aspergillus fumigatus by morphological characteristics and growth at $50^{\circ} \mathrm{C}$. Morphology and BenA sequencing enabled us to identify three isolates as Aspergillus flavus, and one as Aspergillus sydowii. All antifungal drugs tested showed low MIC values, ranging from 0.008 to $1 \mathrm{mg} / \mathrm{L}$. Aspergillosis in birds causes high economic losses and could be controlled by sanitation, avoidance of moldy food, nest and litter and reducing stress factors.
\end{abstract}

Keywords: Aspergillus flavus. Aspergillus fumigatus. Aspergillosis. Birds. Antifungal susceptibility test.

\section{RESUMO}

As espécies de Aspergillus são amplamente distribuídas em todo o mundo e são capazes de desenvolver formas de vida parasitárias e saprófitas, permitindo que Aspergillus infecte hospedeiros vivos, incluindo plantas, insetos, pássaros e mamíferos. A forma mais comum de aspergilose em aves domésticas e outras aves são infecções respiratórias. As manifestações clínicas dependem da dose infecciosa, doenças pré-existentes e da resposta imune do hospedeiro. O objetivo da presente investigação foi estudar aspergilose em aves domésticas e silvestres da Argentina. Foi realizada a identificação morfológica e molecular, assim como a determinação do teste de suscetibilidade contra sete drogas antifúngicas. Foram estudadas seis aves pertencentes a diferentes cidades da província argentina de Buenos Aires. Três das amostras pertenciam a frangos de corte, enquanto as outras três amostras pertenciam a uma águia, um faisão e uma gaivota. Dois isolados foram identificados como Aspergillus fumigatus por características morfológicas e crescimento a $50^{\circ} \mathrm{C}$. A morfologia e o sequenciamento de BenA permitiram identificar três isolados como Aspergillus flavus e um como Aspergillus sydowii. Todos os antifúngicos testados apresentaram baixos valores de CIM, variando de 0,008 a $1 \mathrm{mg} / \mathrm{L}$. Aspergilose em aves causam altas perdas econômicas e podem ser controladas por práticas de higiene, evitando alimentos, ninhos e cama mofados e reduzindo os fatores de estresse.

Palavras-chave: Aspergillus flavus. Aspergillus fumigatus. Aspergilose. Aves. Teste de sensibilidade antifúngica. 
Correspondence to:

Romina Della Vedova

Universidad Nacional de La Plata, Facultad de Ciencias

Veterinarias, Departamento de Microbiología

60 y 118

1900, La Plata - Buenos Aires, Argentina

e-mail: romidellavedova@gmail.com

Received: December 07, 2018

Approved: May 05, 2019
How to cite: Della Vedova R, Hevia A, Vivot W, Fernández J, Córdoba SB, Reynaldi FJ. Aspergillosis in domestic and wild birds from Argentina. Braz J Vet Res Anim Sci. 2019;56(2):e152460. https://doi.org/10.11606/issn.1678-4456. bjvras.2019.152460

\section{Introduction}

Aspergillus species are widely distributed throughout the world and can develop both parasitic and saprophytic ways of life. This particularity allows Aspergillus to infect living hosts, including plants, insects, birds and mammals (Heitman, 2011; Pitt, 1994). Aspergillosis is the fungal infection caused by some species that belong to the genus Aspergillus, affecting mostly the respiratory tract of humans and other animals, with a higher occurrence in birds than mammals (Copetti et al., 2015; Tell, 2005). The fungal infection can affect domestic and wild birds; moreover, it is one of the most frequent causes of death in birds living in captivity (zoos), particularly aquatic wild birds (Arné et al., 2011).

Aspergillus fumigatus is the more frequent etiological agent of aspergillosis; however, A. flavus, A. niger, A. glaucus, A. nidulans, and other Aspergillus species or mixed infections can play a role in this disease (Barton et al., 1992; Joseph, 2000; Perelman \& Kuttin, 1992). In relation to A. fumigatus, several authors considered that this is the predominant species of airborne fungal infections, probably due to the size of their spores, which are smaller than those of other Aspergillus species (Beernaert et al., 2010; Richard \& Thurston, 1983).

The most common forms of animal aspergillosis are respiratory infections in poultry and other birds. Clinical manifestations depend on the infective dose, spore distribution, pre-existing diseases, and immune response of the host (Dahlhausen et al., 2004). Avian aspergillosis is often classified as acute or chronic. Acute aspergillosis is thought to be the result of inhaling an overwhelming number of spores, and generally in young birds with high rates of morbidity-mortality; while chronic aspergillosis is generally associated with sporadic cases in older birds suffering immune suppression or concomitant diseases (Beernaert et al., 2009; Vanderheyden, 1993). To date, there are several reported cases of avian aspergillosis caused by strains of Aspergillus resistant to antifungal agents (Beernaert et al., 2009; Ziołkowska et al., 2014).

The aim of this investigation was to study aspergillosis in domestic and wild birds from Argentina. For this purpose, we carried out morphological and molecular identification, and antifungal susceptibility testing.

\section{Material and Methods}

\section{Birds studied}

We studied six birds from different cities in Buenos Aires, Argentina. Three of the samples belonged to broiler chicks (Gallus gallus domesticus) of 10,14 and 15 days old, respectively, from different productive farms in Buenos Aires Province, one sample came from a 4-year old eagle (Geranoaetus melanoleucus) belonging to the La Plata City Zoo, one sample from a one-year old domestic pheasant (Lophura swinhoii) from a family that bought it in a pet store in La Plata City, and one sample from a dead kelp gull (Larus dominicanus) found on the seashore of Valeria City, in Valeria del Mar southeast of Buenos Aires Province. Information on the clinical history of the wild birds was scarce due their origin.

\section{Microscopic observation}

The broiler samples were collected from the lungs, the eagle's from the lung and air sacs, the pheasant's from the caeca and pleura, and the kelp gull's from the lungs and air sacs. These organ fragments showed lesions suggestive of aspergillosis (e.g., granulomas, haemorrhages and greenish-yellow cottony textures) and were analyzed with direct microscopy, by preparing a wet smear using Gueguen's contrast solution to facilitate the observation of fungal hyphae. Samples of the affected tissue (measuring $0.5-1 \mathrm{~cm}^{3}$ ) were stained with hematoxylin and eosin (H/E) for microscopic evaluation (Gornatti Churria et al., 2012; Leishangthem et al., 2015).

\section{Characteristic of cultures}

All samples were cultured in Sabouraud dextrose agar (SDA), potato dextrose agar (PDA), added with $0.05 \mathrm{~g} / \mathrm{L}$ of chloramphenicol. The incubation was performed at $25^{\circ} \mathrm{C}$ and $37^{\circ} \mathrm{C}$ for a period of 3-5 days. In all isolates, macromorphology and micromorphology were evaluated on Czapek yeast autolysate agar (CYA) and malt extract 
agar (MEA) (Oxoid, Buenos Aires, Argentina) at $25^{\circ} \mathrm{C}$ (Pfaller et al., 2011). When necessary, growth at $50^{\circ} \mathrm{C}$ on CYA was done to improve the accuracy of the microbiological identification (Samson et al., 2014).

\section{Molecular identification}

Molecular data from B-tubuline gene (Ben A) was used to confirm the morphological identification (Samson et al., 2014). Briefly, DNA extraction: conidial suspensions $\left(10^{6}-10^{8}\right.$ conidia $\left./ \mathrm{mL}\right)$ were seeded in small Petri dishes $(6 \mathrm{~cm}$ diameter) containing MEY broth ( $1 \%$ malt extract, $0.4 \%$ yeast extract, $0.4 \%$ dextrose; $4 \mathrm{~mL} /$ plate) and incubated at $25{ }^{\circ} \mathrm{C}$ until processing. Mycelium was collected with a pipette tip and dried completely on sterile Whatman filter paper $\mathrm{N}^{\circ} 2$. Dried mycelium was transferred to a $50 \mathrm{~mL}$ tube, where $4 \mathrm{~mm}$ sterile glass beads were added. Mycelium was ground by placing it in liquid nitrogen for $1 \mathrm{~min}$ and vortexing at maximum speed for $30 \mathrm{sec}$. The mycelium powder was resuspended in $800 \mu \mathrm{l}$ of lysis buffer (200 mmol Tris- $\mathrm{HCl}, 500 \mathrm{mmol} \mathrm{NaCl}$, 10 mmol EDTA, 1\% SDS) and DNA was extracted with phenol-chloroform-isoamyl alcohol (25:24:1), precipitated with isopropanol and washed with $70 \%$ ethanol. Dried DNA pellet was resuspended in $100 \mu \mathrm{L}$ of sterile distilled water and stored at $-20{ }^{\circ} \mathrm{C}$ until use.

Polymerase chain reaction (PCR) amplification and sequencing: the Ben $A$ amplification was carried out using $2 \mathrm{mmol} \mathrm{MgCl} 2,250 \mu \mathrm{mol}$ dNTPs, TRIS-HCl $20 \mathrm{mmol}$ (pH 8,4), $\mathrm{KCl}$ 50mmol, $2.5 \mathrm{U}$ Taq DNA polymerase (Invitrogen, Life Technologies, Carlsbad, CA, USA), $0.2 \mu \mathrm{mol}$ of each primer, Bt2a ( $5^{\prime}$ - GGTAACCAAATCGGTGCTGCTTTC $\left.-3^{\prime}\right)$ and Bt2b (5' - ACCCTCAGTGTAGTGACCCTTGGC - $3^{\prime}$ ) and 10 ng DNA template, in a $50 \mu \mathrm{l}$ PCR assay (Samson et al., 2014).

Thermal cycling was performed using the Applied Biosystems Veriti ${ }^{\mathrm{TM}} 96$ well Thermal Cycler (Applied Biosystems, Foster City, CA, USA), under the following conditions: an initial denaturation step at $94^{\circ} \mathrm{C}$ for $10 \mathrm{~min}$, followed by 35 cycles of denaturation at $94^{\circ} \mathrm{C}$ for $1 \mathrm{~min}$, annealing at $55^{\circ} \mathrm{C}$ for $1 \mathrm{~min}$ and extension at $72^{\circ} \mathrm{C}$ for $1 \mathrm{~min}$, and a final extension step at $72^{\circ} \mathrm{C}$ for $10 \mathrm{~min}$. PCR products were sequenced on both strands, using a Big Dye Terminator kit and the 3500 ABI genetic analyzer (Applied Biosystems). The sequences obtained were edited using Bioedit Sequence Alignment Editor v7.0.4.1 and sequence similarities were searched and retrieved from the NCBI GenBank database using the BLAST algorithm with automatically adjusted parameters.

\section{Antifungal susceptibility test}

The minimal inhibitory concentration (MIC) of antifungal drugs was determined according to the Clinical and Laboratory Standards Institute (CLSI) M38 $3^{\text {rd }}$ Ed. broth microdilution reference document (Clinical and Laboratory Standards Institute, 2017).

The following antifungal drugs were evaluated: amphotericin $\mathrm{B}$ and itraconazole, caspofungin and posaconazole (Merck and Co., Buenos Aires, Argentina), voriconazole and anidulafungin (Pfizer, S.A, Buenos Aires, Argentina), terbinafine (Panalab, Buenos Aires, Argentina), micafungin (Raffo-Astellas Buenos Aires, Argentina). In all cases, the antifungal drugs were provided as standard powders of known potency.

The stock solutions of each antifungal drug were prepared with dimethyl sulfoxide (Merck and Co.), and diluted with RPMI 1640 media (Merck and Co.). The final concentration used for all antifungals ranged from 0.0313 to $16 \mathrm{mg} / \mathrm{L}$ and was placed on 96-well microdilution plates (Nunclon 167008, Nunc, Naperville, IL, USA).

The inoculum was prepared in $5 \mathrm{~mL}$ of sterile water supplemented with $0.1 \%$ Tween 20 and was adjusted to obtain a final working concentration of $0.4-5 \times 10^{4} \mathrm{CFU} / \mathrm{ml}$. Then, microdilution plates were incubated without agitation at $35^{\circ} \mathrm{C}$ and were read at $24 \mathrm{~h}$ for echinocandins, and at $48 \mathrm{~h}$ for the other antifungal drugs.

Quality control strains: Aspergillus fumigatus ATCC 204304, Aspergillus flavus ATCC 204305 were used.

\section{Endpoints}

For amphotericin B and azoles, the MIC endpoint was defined as the lowest concentration of drug that caused the complete growth inhibition (100\%). For terbinafine, $80 \%$ inhibition was considered, while for anidulafungin, caspofungin and micafungin, the minimum effective concentration (MEC) endpoint was determined. MEC was defined as the minimal concentration of drug that caused visible morphological changes of the hyphae, causing the interruption of growth.

The MIC endpoint was read visually with the help of a mirror, while an inverted light microscope was used to determine the MEC.

To date, CLSI has not defined clinical breakpoints for mold against antifungal agents; thus, we could not classify the isolates as either susceptible or resistant.

However, epidemiological cutoff values (ECVs) are available for some antifungal drugs and some Aspergillus spp. (Espinel-Ingroff et al., 2011, 2017, 2018; Pfaller et al., 2009, 2011).

In the absence of clinical breakpoints, the ECV is a useful tool to distinguish the wild-type (WT) population, which is 
the population of microorganisms in a microorganism/drug combination, with no detectable acquired resistance mechanism from the non-wild type (non-WT) populations, which are those that may exhibit acquired or mutational resistance mechanisms to the drug in question.

For A. fumigatus, ECVs were defined for amphotericin B $2 \mathrm{mg} / \mathrm{L}$, for itraconazole and voriconazole $1 \mathrm{mg} / \mathrm{L}$, and for posaconazole $0.5 \mathrm{mg} / \mathrm{L}$.

For A. flavus, ECVs were defined for amphotericin B $4 \mathrm{mg} / \mathrm{L}$, for itraconazole and voriconazole $1 \mathrm{mg} / \mathrm{L}$, and for posaconazole $0.25 \mathrm{mg} / \mathrm{L}$.

In addition, geometric mean, MIC-0, mode, and range were calculated for all drugs tested. Data were analyzed using the data analysis software system Statistica, version 7.1, Tulsa, OK, USA (StatSoft, 2018).

\section{Results}

\section{Histopathology}

In all cases, the fresh examination of samples and Gueguen's contrast solution showed typical hyphae of Aspergillus spp. characterized by septate and dichotomously branched structures with thin-walled parallel hyphal elements. In some cases, we could see the conidial head of Aspergillus spp. (Figure 1). For the eagle's lung and air sacs case, the pheasant's caeca and pleura, and the kelp gull's lungs and air sacs, with $\mathrm{H} / \mathrm{E}$ stain we observed the presence of nodules consisting of a central mass of necrotic exudate within typical and numerous hyphae of Aspergillus spp. On the other hand, in the broiler lung samples, we could not detect the presence of nodules; however, we could see in the lung tissue inflammatory cell reaction of heterophils,

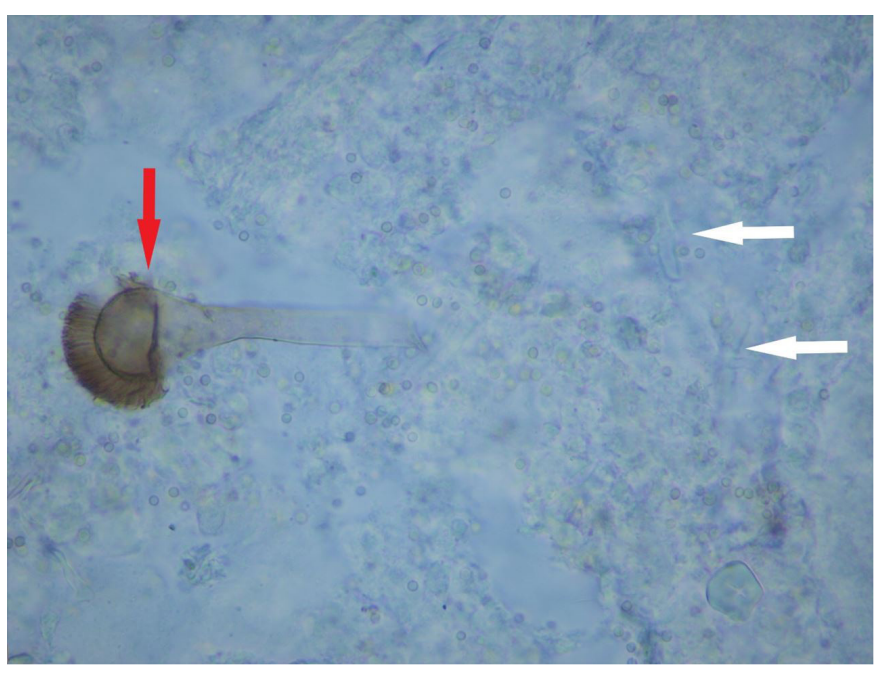

Figure 1 -Fresh examination of samples with Gueguen's contrast solution. The white arrows show typical hyphae of Aspergillus spp, and the red arrow highlights the conidial head of Aspergillus spp. macrophages, lymphocytes and multinucleated cells. Moreover, numerous and typical hyphae of Aspergillus spp. were seen in air passages and interstitial tissue. Even though the H/E is not the best option to highlight fungal elements, we could clearly detect hyphae septate, dichotomously branched, in all the studied cases (Figure 2).

\section{Culture characteristic and molecular identification}

From the six isolates studied, two were identified as A. fumigatus (from a kelp gull and an eagle) by morphological characteristics and growth at $50{ }^{\circ} \mathrm{C}$. Morphology and $B e n A$ sequencing enabled us to identify three isolates as A. flavus (from broiler chicks) and one as A. sydowiiI (from a pheasant). The micromorphological structures are shown in Figure 3A-C. All isolates are stored and conserved at the Mycology Department Culture Collection of the INEIA- ANLIS “Dr. Carlos G. Malbrán”, Buenos Aires, Argentina.

\section{Susceptibility test}

Overall, the antifungal drugs tested showed low MIC values, ranging from 0.008 to $1 \mathrm{mg} / \mathrm{L}$. All the species tested were classified as WT taking into account the ECV proposed for amphotericin $\mathrm{B}$, itraconazole, voriconazole and posaconazole. The results of in vitro susceptibility test are summarized in Table 1.

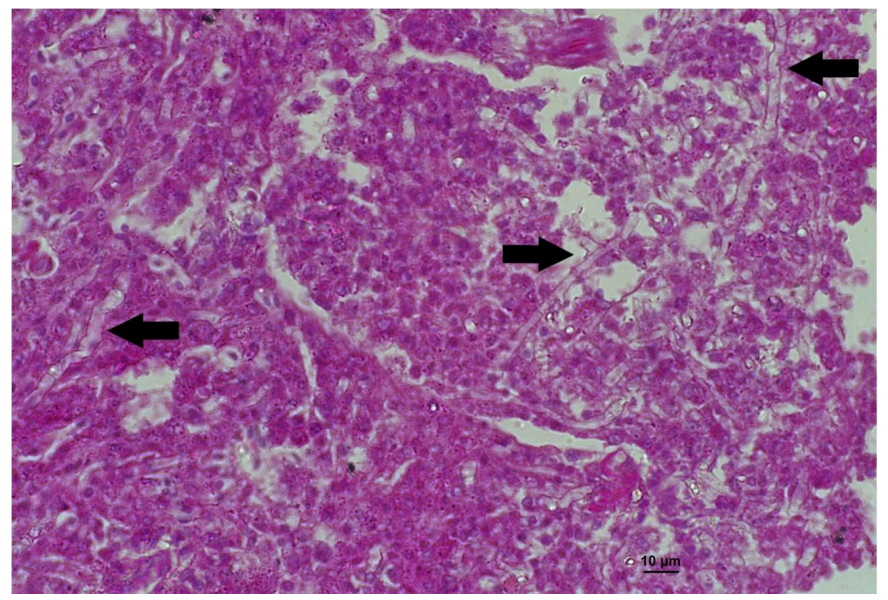

Figure 2 - Tissue section from the lung of the eagle (Geranoaetus melanoleucus) showing numerous septate hyphae typical of Aspergillus spp. (black arrows) H\&E, $400 \mathrm{X}$.

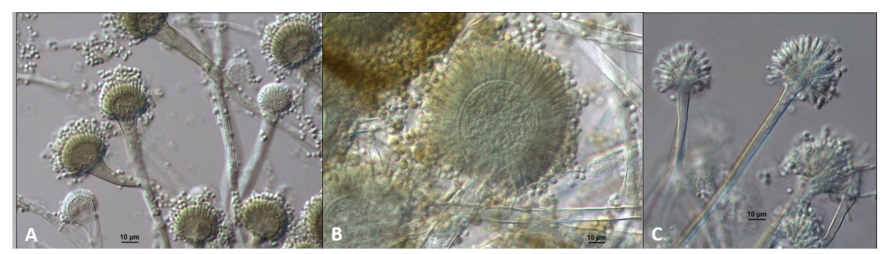

Figure 3 -Micromorphological structures of Aspergillus species (A) A. fumigatus; (B) A. flavus; (C) A. sydowii, (A-C 400x, DIC). 
Table 1 - MIC values of antifungal drugs against Aspergillus species

\begin{tabular}{llllllllll}
\hline \multirow{2}{*}{ Code } & \multirow{2}{*}{ Species } & \multicolumn{10}{c}{ Antifungal drugs. MIC values mg/L } \\
\cline { 3 - 9 } & & AB & TB & IZ & VZ & PZ & MC & CAS & ANID \\
\hline CMN 146-611A & A. flavus & 0.5 & 0.125 & 0.125 & 0.5 & 0.125 & 0.015 & 0.015 & 0.015 \\
CMN 147-619 & A. fumigatus & 1 & 0.25 & 0.5 & 0.25 & 0.06 & 0.015 & 0.03 & 0.015 \\
CMN 144-622 & A. flavus & 1 & 0.125 & 0.5 & 0.5 & 0.25 & 0.015 & 0.03 & 0.015 \\
CMN 145-611 & A. flavus & 0.5 & 0.125 & 0.25 & 0.5 & 0.25 & 0.015 & 0.015 & 0.015 \\
CMN 2-400 & A. sydowii & 0.5 & 0.06 & 0.25 & 0.5 & 0.125 & 0.008 & 0.015 & 0,008 \\
CMN 94-529 & A. fumigatus & 1 & 0.125 & 0.5 & 0.25 & 0.06 & 0.06 & 0.06 & 0,03 \\
& GM & 0.71 & 0.12 & 0.31 & 0.40 & 0.12 & 0.02 & 0.02 & 0.02 \\
& MIC-0 & 1 & 0.25 & 0.5 & 0.5 & 0.25 & 0.06 & 0.06 & 0.03 \\
& Mode & 0.5 & 0.125 & 0.5 & 0.5 & 0.125 & 0.015 & 0.015 & 0.015 \\
& Range & $0.5-1$ & $0.06-0.25$ & $0.125-0.5$ & $0.25-0.5$ & $0.06-0.25$ & $0.008-0.015$ & $0.03-0.06$ & $0.03-0.015$ \\
\hline
\end{tabular}

$\mathrm{GM}=$ geometric mean; MIC-0 = minimal inhibitory concentration that inhibits at $100 \%$ of isolates; $\mathrm{AB}=$ amphotericin $\mathrm{B}$; $\mathrm{TB}=$ terbinafine; $\mathrm{IZ}=$ itraconazole; $\mathrm{VZ}=$ voriconazole; $\mathrm{PZ}=$ posaconazole; $\mathrm{MC}=$ micafungin; $\mathrm{CAS}=$ caspofungin; $\mathrm{ANID}=$ anidulafungin.

\section{Discussion}

Several species of Aspergillus are defined as etiological agents of aspergillosis, which are characterized by being saprophytic filamentous fungi commonly found in soil. For this reason, it is defined as an opportunistic infection with a wide range of living hosts, such as mammals, birds, insects and plants (Pitt, 1994). Moreover, it can cover a wide range of diseases from localized conditions to fatal disseminated infections in both humans and animals (Arné et al., 2011; Tell, 2005).

In animals, aspergillosis is the most common opportunistic infection of the respiratory tract, causing high morbidity and mortality (Leishangthem et al., 2015), with A. fumigatus the most prevalent species in both humans and animals (Arné et al., 2011; Seyedmousavi et al., 2015; Talbot et al., 2018). In our study, we could isolate three different Aspergillus species (A. flavus, A. fumigatus and A. sydowii). A. fumigatus was isolated from a kelp gull and an eagle. These findings agree with several authors that affirm that $A$. fumigatus is the most prevalent etiological agent of aspergillosis.

We have no clinical data from the kelp gull since it was found dead on the seashore, but it is possible that pollution of the coasts due to plastic bags, rotting food, etc., contributed to inadequate feeding of this bird, which could make it more susceptible to infection by A. fumigatus.

Regarding the eagle, this wild bird lived in captivity in the zoo and received the habitual diet, although it also usually received inadequate food from visitors. Thus, it is possible that some digestive alterations occurred causing decreased defenses and the inability to control the fungal infection.

We isolated A. flavus from three different broiler chick samples. These results are also in agreement with authors that proposed A. flavus as one of the most common Aspergillus isolated from chicken farms (Barton et al., 1992; Martin et al., 2007). Some authors believe that A. flavus is more prevalent than A. fumigatus in tropical countries (Wang et al., 2012); however, we isolated A. flavus from three different farms from Buenos Aires Province, which has a temperate climate.

The most particular finding of our study was the strain of A. sydowii isolated from a pheasant. Although this Aspergillus species has already been detected in humans and in sea fan corals (Gorgonia species) (Rypien et al., 2008; Seyedmousavi et al., 2015), to our knowledge, this is the first reported case of disseminated aspergillosis in birds by this aspergillus species.

This species is included in the Nidulantes section according to morphological and molecular studies. This section also includes $A$. nidulans (already reported in birds, dogs and horses) (Arné et al., 2011; Ludwig et al., 2005) and A. versicolor (already reported in dogs and horses) (Ludwig et al., 2005). It is difficult to explain the pathogenic role of $A$. sydowii in the pheasant, while the other wild birds had A. fumigatus.

A. sydowii has been related to severe infections in aquatic inhabitants such as fan corals (Seyedmousavi et al., 2015), although this fungus is also found more often in indoor environments as a contaminant of papers, nuts, beans and straws, among other substrates. Our hypothesis is that the domestic pheasant could be stressed due to inadequate handling and feeding, e.g. receiving food contaminated with high concentrations of conidia of $A$. sydowii.

In relation to the antifungal in vitro susceptibility of our isolates, all were classified as WT considering the ECV proposed for amphotericin $\mathrm{B}$, itraconazole, voriconazole and posaconazole. On the other hand, some authors have already reported up to $100 \%$ resistance for amphotericin B and $35.7 \%$ for itraconazole for Aspergillus species isolated from lungs (Ziołkowska et al., 2014). Regarding these findings, and in accordance with Beernaert et al. (2010), molecular identification and antifungal susceptibility testing of isolates is necessary in veterinary medicine.

Considering that aspergillosis can cause high economic losses in poultry farms and can also contaminate the environment with Aspergillus strains potentially pathogenic 
for humans, it is necessary to conduct regular monitoring of the presence and drug susceptibility of Aspergillus species both inside and in the vicinity of poultry farms. The disease could be controlled by sanitation and avoidance of moldy feed and litter, reducing stress factors.

\section{Conflict of Interest}

The authors state they have no conflicts of interest to declare.

\section{References}

Arné P, Thierry S, Wang D, Deville M, Le Loc'h G, Desoutter A, Féménia F, Nieguitsila A, Huang W, Chermette R, Guillot J. Aspergillus fumigatus in poultry. Int J Microbiol. 2011;2011:746356. http://dx.doi.org/10.1155/2011/746356. PMid:21826144.

Barton JT, Daft BM, Read DH, Kinde H, Bickford AA. Tracheal aspergillosis in $61 / 2$-week-old chickens caused by Aspergillus flavus. Avian Dis. 1992;36(4):1081-5. http:// dx.doi.org/10.2307/1591580. PMid:1485863.

Beernaert LA, Pasmans F, Van Waeyenberghe L, Dorrestein GM, Verstappen F, Vercammen F, Haesebrouck F, Martel A. Avian Aspergillus fumigatus strains resistant to both itraconazole and voriconazole. Antimicrob Agents Chemother. 2009;53(5):2199-201. http://dx.doi.org/10.1128/AAC.0149208. PMid:19258265.

Beernaert LA, Pasmans F, Van Waeyenberghe L, Haesebrouck F, Martel A. Aspergillus infections in birds: a review. Avian Pathol. 2010;39(5):325-31. http://dx.doi.org/10.1080/0307 9457.2010.506210. PMid:20954008.

CLSI: Clinical and Laboratory Standards Institute. CLSI standard M38: reference method for broth dilution antifungal susceptibility testing of filamentous fungi. 3rd ed. Wayne: CLSI; 2017.

Copetti MV, Barcelos AS, Kommers GD, Santurio JM, Oliveira FN, Lovato M. Cutaneous, respiratory and hepatic aspergillosis in brazilian white pekin mallards (Anas platyrhynchos). Mycopathologia. 2015;179(3-4):321-5. http:// dx.doi.org/10.1007/s11046-014-9833-6. PMid:25481845.

Dahlhausen B, Abbott R, Vanoverloop P. Rapid detection of pathogenic Aspergillus species in avian samples by realtime PCR assay: a preliminary report. In: Bergman E, editor. Proceedings of the 25th Annual Conference \& Expo of the Association of Avian Veterinarians; 2004; New Orleans,

\section{Ethics Statement}

All authors have been personally and actively involved in the manuscript, and are jointly and individually responsible for their content.

\section{Acknowledgements}

The authors gratefully acknowledge to MV Celina Buscaglia and Zoo of La Plata city for samples contribution.

LA, USA. Teaneck: Association of Avian Veterinarians; 2004. p. 37.

Espinel-Ingroff A, Arendrup M, Cantón E, Cordoba S, Dannaoui E, García-Rodríguez J, Gonzalez GM, Govender NP, Martin-Mazuelos E, Lackner M, Lass-Flörl C, Linares Sicilia MJ, Rodriguez-Iglesias MA, Pelaez T, Shields RK, Garcia-Effron G, Guinea J, Sanguinetti M, Turnidge J. Multi-center study of method-dependent epidemiological cutoff values for detection of resistance in Candida spp. and Aspergillus spp. to amphotericin B and echinocandins for the Etest agar diffusion method. Antimicrob Agents Chemother. 2017;61(1):e01792-16. http://dx.doi.org/10.1128/ AAC.01792-16. PMid:27799206.

Espinel-Ingroff A, Cuenca-Estrella M, Fothergill A, Fuller J, Ghannoum M, Johnson E, Pelaez T, Pfaller MA, Turnidge J. Wild-type MIC distributions and epidemiological cutoff values for amphotericin B and Aspergillus spp. for the CLSI broth microdilution method (M38-A2 document). Antimicrob Agents Chemother. 2011;55(11):5150-4. http:// dx.doi.org/10.1128/AAC.00686-11. PMid:21876047.

Espinel-Ingroff A, Turnidge J, Alastruey-Izquierdo A, Dannaoui E, Garcia-Effron G, Guinea J, Kidd S, Pelaez T, Sanguinetti M, Meletiadis J, Botterel F, Bustamante B, Chen YC, Chakrabarti A, Chowdhary A, Chryssanthou E, Córdoba S, Gonzalez GM, Guarro J, Johnson EM, Kus JV, Lass-Flörl C, Linares-Sicilia MJ, Martín-Mazuelos E, Negri CE, Pfaller MA, Tortorano AM. Posaconazole MIC distributions for Aspergillus fumigatus SC by four methods: impact of Cyp51A mutations on estimation of epidemiological cutoff values. Antimicrob Agents Chemother. 2018;62(4):e01916-17. http://dx.doi.org/10.1128/AAC.01916-17. PMid:29437624.

Gornatti Churria D, Reynaldi FJ, Origlia J, Marcantoni HA, Píscopo MV, Herrero Loyola MA, Reinoso EH, Petruccelli MA. Pulmonary aspergillosis due to Aspergillus flavus infection in a captive Eclectus parrot (Eclectus roratus). Braz J Vet Pathol. 2012;5(1):4-6. 
Heitman J. Microbial pathogens in the fungal kingdom. Fungal Biol Rev. 2011;25(1):48-60. http://dx.doi.org/10.1016/j. fbr.2011.01.003. PMid:21528015.

Joseph V. Aspergillosis in raptors. Seminars in Avian and Exotic Pet Medicine. 2000;9(2):66-74. http://dx.doi. org/10.1053/AX.2000.4617.

Leishangthem GD, Singh ND, Brar RS, Banga HS. Aspergillosis in avian species: a review. Journal of Poultry Science and Technology. 2015;31:1-14.

Ludwig A, Gatineau S, Reynaud MC, Cadoré JL, Bourdoiseau G. Fungal isolation and identification in 21 cases of guttural pouch mycosis in horses (1998-2002). Vet J. 2005;169(3):457-61. http://dx.doi.org/10.1016/j. tvjl.2004.06.005. PMid:15848789.

Martin MP, Bouck KP, Helm J, Dykstra MJ, Wages DP, Barnes HJ. Disseminated Aspergillus flavus in broiler breeder pullets. Avian Dis. 2007;51(2):626-31. http:// dx.doi.org/10.1637/0005-2086(2007)51[626:DAFIIB]2.0. CO;2. PMid:17626498.

Perelman B, Kuttin ES. Aspergillosis in ostriches. Avian Pathol. 1992;21(1):159-63. http://dx.doi. org/10.1080/03079459208418830. PMid:18670927.

Pfaller MA, Castanheira M, Messer SA, Moet GJ, Jones RN. Echinocandin and triazole antifungal susceptibility profiles for Candida spp., Cryptococcus neoformans and Aspergillus fumigatus: application of new CLSI clinical breakpoints and epidemiologic cutoff values to characterize resistance in the SENTRY Antimicrobial Surveillance Program (2009). Diagn Microbiol Infect Dis. 2011;69(1):45-50. http://dx.doi. org/10.1016/j.diagmicrobio.2010.08.013. PMid:21146713.

Pfaller MA, Diekema DJ, Ghannoum MA, Rex JH, Alexander BD, Andes D, Brown SD, Chaturvedi V, EspinelIngroff A, Fowler CL, Johnson EM, Knapp CC, Motyl MR, Ostrosky-Zeichner L, Sheehan DJ, Walsh TJ. Wild-type MIC distribution and epidemiological cutoff values for Aspergillus fumigatus and three triazoles as determined by the Clinical and Laboratory Standards Institute broth microdilution methods. J Clin Microbiol. 2009;47(10):3142-6. http://dx.doi.org/10.1128/JCM.00940-09. PMid:19692559.

Pitt JI. The current role of Aspergillus and Penicillium in human and animal health. J Med Vet Mycol. 1994;32(Suppl 1):17-32. http://dx.doi.org/10.1080/02681219480000701. PMid:7722784.
Richard JL, Thurston JR. Rapid hematogenous dissemination of Aspergillus fumigatus and A. flavus spores in turkey poults following aerosol exposure. Avian Dis. 1983;27(4):1025-33. http://dx.doi.org/10.2307/1590203. PMid:6418131.

Rypien KL, Andras JP, Harvell CD. Globally panmictic population structure in the opportunistic fungal pathogen Aspergillus sydowii. Mol Ecol. 2008;17(18):4068-78. http:// dx.doi.org/10.1111/j.1365-294X.2008.03894.x. PMid:18684135.

Samson RA, Visagie CM, Houbraken J, Hong SB, Hubka V, Klaassen CHW, Perrone G, Seifert KA, Susca A, Tanney JB, Varga J, Kocsubé S, Szigeti G, Yaguchi T, Frisvad JC. Phylogeny, identification and nomenclature of the genus Aspergillus. Stud Mycol. 2014;78(1):141-71. http://dx.doi. org/10.1016/j.simyco.2014.07.004. PMid:25492982.

Seyedmousavi S, Guillot J, Arné P, De Hoog GS, Mouton JW, Melchers WJG, Verweij PE. Aspergillus and aspergilloses in wild and domestic animals: a global health concern with parallels to human disease. Med Mycol. 2015;53(8):765-97. http://dx.doi.org/10.1093/mmy/myv067. PMid:26316211.

StatSoft [Internet]. Tulsa: StatSoft; 2018 [cited 2018 dec 7]. Available from: www.statsoft.com

Talbot JJ, Thompson P, Vogelnest L, Barrs VR. Identification of pathogenic Aspergillus isolates from captive birds in Australia. Med Mycol. 2018;56(8):1038-41. http://dx.doi. org/10.1093/mmy/myx137. PMid:29228225.

Tell LA. Aspergillosis in mammals and birds: impact on veterinary medicine. Med Mycol. 2005;43(Suppl 1):S71-3. http://dx.doi.org/10.1080/13693780400020089. PMid:16110795.

Vanderheyden N. Aspergillosis in psittacine chicks. In: Jackson G, editor. Proceedings of the Annual Conference of the Association of Avian Veterinarians; 1993; Nashville, TN, USA. Teaneck: Association of Avian Veterinarians; 1993. p. 207.

Wang DY, Hadj-Henni L, Thierry S, Arné P, Chermette R, Botterel F, Hadrich I, Makni F, Ayadi A, Ranque S, Huang WY, Guillot J. Simple and highly discriminatory VNTRbased multiplex PCR for tracing sources of Aspergillus flavus isolates. PLoS One. 2012;7(9):e44204. http://dx.doi. org/10.1371/journal.pone.0044204. PMid:23028503.

Ziołkowska G, Tokarzewski S, Nowakiewicz A. Drug resistance of Aspergillus fumigatus strains isolated from flocks of domestic geese in Poland. Poult Sci. 2014;93(5):1106-12. http://dx.doi.org/10.3382/ps.2013-03702. PMid:24795302. 
Financial Support: Provided by Servicio de Micología Médica and Fundación Facultad de Ciencias Veterinarias UNLP, Argentina.

Authors Contributions: Romina Della Vedova conceived the original idea and wrote the manuscript. Alejandra Hevia realized molecular identification of isolates. Walter Vivot was in charge of the technical assistance in susceptibility test. Julián Fernández was in charge of the technical assistance in molecular identification of isolates. Susana Beatriz Córdoba made the susceptibility test, interpretation of results and final revision of manuscript. Francisco José Reynaldi realized microbiological identification of isolates, interpretation of results and final revision of manuscript. 